Corrigendum

December 1999

Volume 104 | Number 12

\title{
Dilated cardiomyopathy in homozygous myosin-binding protein-C mutant mice
}

Bradley K. McConnell, Karen A. Jones, Diane Fatkin, Luis H. Arroyo, Richard T. Lee, Orlando Aristizabal, Daniel H. Turnbull, Dimitrios Georgakopoulos, David Kass, Meredith Bond, Hideshi Niimura, Frederick J. Schoen, David Conner, Donald A. Fischman, Christine E. Seidman, and J.G. Seidman

J. Clin. Invest. 104:1235-1244 (1999).

In the original author list, Donald A. Fischman's name appeared incorrectly. The corrected author list appears above. 